\title{
Terrorism, homeland safety and event management
}

\author{
Geoffrey R. Skoll
}

Criminal Justice Department, Buffalo State College,

1300 Elmwood Avenue,

Buffalo, NY 14222, NY, USA

E-mail: skollgr@buffalostate.edu

\section{Maximiliano E. Korstanje*}

Department of Economics, University of Palermo,

Larrea 10763 Floor Buenos Aires, Argentina

E-mail: mkorst@palermo.edu

*Corresponding author

\begin{abstract}
As the last attacks on Boston showed terrorism is based not only on speculation but also on surprise. Terrorists do not want to destroy or to kill everybody, their goal is aimed to inflict and administrate fear to the witnesses. The fact is that tourism and mega-events represented a fertile source to perpetrate terrorist attacks, not only for the casualties but also by the psychological effects on citizenry. This paper explores the nature of terrorism in the context of leisure as well as proposing a valid model to understand the connection among tourism, event management and terrorism.
\end{abstract}

Keywords: terrorism; fear; event management; tourism; leisure; rules; surprise.

Reference to this paper should be made as follows: Skoll, G.R. and Korstanje, M.E. (2014) 'Terrorism, homeland safety and event management', Int. J. Hospitality and Event Management, Vol. 1, No. 1, pp.95-110.

Biographical notes: Geoffrey R. Skoll is an Associate Professor of Criminal Justice at Buffalo State College, State University of New York. His research area includes terrorism and security, postmodernity, and cultural sociology. His recent publications include two books, Contemporary Criminology and Social Theory of Fear, both published by Palgrave Macmillan.

Maximiliano E. Korstanje is an Associate Professor of University of Palermo and the Editor in Chief of International Journal of Safety and Security in Tourism/Hospitality. His research areas are risk perception and disaster-management. With more than 300 published papers and 15 books, he works as editorial board member of more than 20 tourism and disaster-related journals and international councils dedicated to the studies of risk. 


\section{Introduction}

The conceptual limit for defining tourists' risks as those aspects which may jeopardise the well-being of tourists seems to be unquestionable. As Tarlow (2011) put it, their vulnerability and their lack of familiarity make tourists a prey for crime and terrorist attacks. The prosperity of economies which adopt tourism as a chief industry depends on the image of destinations. Of almost all risks, terrorism today is the major topic that concerns policy makers in tourism and hospitality. However, it becomes a buzz word with many significations. Though terrorism represents serious problems for the industry of tourism because of its dependence on local economies, it is very hard to define this issue with accuracy. Under some conditions, peripheral countries developed a paradoxical situation. At one time, they adopt events and festivals to mitigate the problems of poverty, and by doing so, local resentment is triggered by the material asymmetries found in these events, which then present a clear target to attack. First, we have to define what we understand by terrorism and mediated events to give a fresh conceptual model to evaluate the problem.

It is interesting to discuss to what extent mega events are a fertile source for terrorism. Terrorism introduces a message in society aimed at undermining states or creating political instability. From immemorial times, human beings have managed festivals and mega-events not only to celebrate a good harvest, but also to strengthen the social bond. Mediated events are, at least, significant celebrations that contribute socially to the reproduction of society. In view of this, some groups which are antagonistic to the state, attack against attendees at the events as a way to create panic, undermining not only the legitimacy of government but the trust of citizens in their institutions. This double effect has been widely studied by sociologists and anthropologists in terrorism related issues. However, less attention has been given to the fact that leisure spaces are preferred by terrorists to plan their acts. This raises an interesting point of debate based on the connection between terrorism, leisure, and mega-events that deserves to be continued, what is terrorism? What terrorists opt to target festivals and events? Is the nation state able to prevent the next attack? Why does leisure represent a fertile source for terrorism? The present essay explores the literature on terrorism and hospitality, and focuses on the importance leisure spaces have for terrorists. Our goals are aimed at discussing the diverse definition of terrorism as well as proposing a theory to understand its effects on social imaginary. Terrorism works by the psychological fear it can instil on targeted populations.

Effects of terrorism in public spectacles depend on four variables.

- Threshold of control: this factor exhibits the degree of control the society exerts on the event. For example, bombing can be more easily and visually monitored than food contamination by micro-organisms.

- Probability of repetition signals that the troubling event can be repeated in a short run. This means that the state lacks the necessary resources to prevent a similar attack in the future.

- Targeted victims refer to the status of casualties. Societies valorise some groups over others. Whenever targeted victims represent children or vulnerable women, because they are the biological background of community, people panic. 


\section{Preliminary debate}

Although terrorism has been posed as a serious challenge for the West in last few decades, the fact is that the misunderstanding of what it means is rising. In view of this, Moten (2010) argues that terrorism is colourised by ideology or location. As an instrument of struggle, it connotes a group of rebels and a state which attempts to impose its hegemony. Summarising the four waves of Rappoport, Moten said that terrorist attacks are more violent and virulent than decades ago. Although the first wave surfaced with the anarchism and its anarcho-syndicalism programmes (1878-1910), a second wave flourished in colonised Africa and Asia from 1920s onwards. Based on a specific occupied soil, rebels struggled by their independence, their attacks were directed to targeted government. Third wave, rather, was associated with the political left in its response to the decline of democracy in Western countries (1970-1980). The last wave was symbolised by the Ayatollah's revolution in Iran 1979, which focused on the radical rejection of secular values. These types of terrorism included bombing cars and suicide bombings. One of the most troubling aspects in defining terrorism is that it serves political interests. Western states call terrorists all those individuals or groups that can destabilise the societal order, while Muslims call terrorists those imperial powers which historically have taken their resources.

We offer the following as a clarification of definitional confusion. More than 30 years ago, the US Task Force on Disorders and Terrorism proposed a serviceable definition as follows. "Terrorism is a tactic or technique by means of which a violent act or threat thereof is used for the purpose of creating overwhelming fear for coercive purposes" [Task Force on Disorders and Terrorism, (1976), p.3]. Shortening it does no harm so a more concise version is "Terrorism (n.): A coercive tactic using fear through violence or its threat." The background for the national Task Force was social turmoil accompanied by an increase in civil disorders during the early 1970s. The Task Force noted numerous airplane hijackings, bombings, and riots in cities in the USA.

Just before the 9/11 attacks, the former staff director of the Task Force weighed in on the definitional controversy. Cooper (2001, p.881) begins by quoting Cohen (1990, pp.41-42). "A living language has no existence independent of culture. It is not the loom of culture but its data bank. As such, it serves the needs, past and present, of a given community. As those needs change, language evolves to accommodate them". Cooper goes on to offer an elegant definition: “... [T] errorism is the intentional generation of massive fear by human beings for the purpose of securing or maintaining control over other human beings" [Cooper, (2001), p.883]. Cooper's 2001 definition does not require violence, but stresses control more than mere coercion. These changes improve the 1976 version as they open the possibility that terrorism is a condition, not merely an event.

A short hand version allows researchers to recognise terrorism when they see it. According to that criterion, terrorism occurs when someone makes people fearful in order to control them. The three elements are intent, fear, and control (Crenshaw, 1983, 1995).

Terrorism related research has advanced in the social sciences according to problems raised in the Cold War. That was up to 9/11, where after, many studies in tourism and hospitality turned their attention to terrorist issues (Hall, 2002; Kozak et al., 2007; Kuto and Groves, 2004; Henderson, 2008; Floyd and Pennington-Gray, 2004; Korstanje, 2009; 
Abdel-Azim, 2010). The hospitality and tourism industry faced serious problems because of the effects of terrorism worldwide (Baker and Coulter, 2007; Atkins et al., 2003). The symbiosis between tourism and terrorism points to the profits of the industry. Many peripheral countries adopt tourism to relieve their economic problems. Mega events provide a fresh source of income to mitigate poverty, but the problem is that these policies should be accompanied with other developmental projects to gain sustainable economic growth. The revitalisation of economies based exclusively on tourism resulted in serious imbalances for tourism-adopting countries. The modern economy of tourism and hospitality in the world of service seems to be subject to intangible experiences. Since the tourist-experience cannot be appreciated once consumed, experts rely on the question of image. The discipline of psychology has played a pivotal role in understanding tourist experiences. Given the context of subjective experience, it is not surprising to see how terrorist try to cause fear by attacking tourists. They aim at creating a message to other tourists in the world, so that they desist from travel to a particular destination. That way, states which rely on tourism, face a downfall in international travel creating a serious economic loss. Terrorism uses mega festivals or events as the platform to portray a message to the world. This situation leads policy makers and police to a paradox: the more attractive a destination is, the more dangerous it may be. The needs of planning for safety not only affect the image of destinations such as Israel or Jordan, but also create a vicious circle in case of attacks. One of the aspects that shocked the public opinion after 9/11 was not the tactic itself, which was based on western marketing and managerial manuals, but the fact it had been perpetrated in the supposed safest nation of the world. If this happened with the USA, a superpower, what could have other countries do where homeland safety appears not to be a priority of state?

$9 / 11$ undoubtedly marked a turning-point that changed the way of perceiving the world forever. The psychological impacts of $9 / 11$ transcended the boundaries of nationhood because of the degree of visual technology developed by the media in West. Terrorists not only employed the West's own means of transport, which created a new tactic of terrorism, but also found in the media a compliant distributor for fear mongering message. Clearly, tourism has been one of the industries most affected by terrorist acts. Terrorism determines the way travellers garner information and imagine their destinations (Peattie et al., 2005). Because of their unfamiliarity with the destination, travellers and tourists are often targets of diverse crimes. Some terrorist cells attack tourists with a double message. On one hand, they inspire a panic in public opinion from the victims' countries of origin. On the other, they undermine the citizenry's trust in the state. Of course, any destination combines risk aversion with risk attraction factors. As Lepp and Gibson (2008) put it, this industry seems to be circumscribed by two contrasting tendencies: the sensation or novelty seeking risk and risk aversion. The type of psychological personality of tourists plays a crucial role at time of determining the perception of risk. In addition, West (2008) considers the terrorist attacks in 2003 to Western tourists in Bali. They have been memorialised by the Australian Press as the archetype of terrorism, comparing this event with $9 / 11$. This means that collective memory and crises are inextricably intertwined in the national discourse. Postmodern nationalisms legitimise travel as a universal benefit to mankind which should be defended at any cost. Similarly, the narrative of terrorism emphasises that enemies of democracy utilise foreign tourists precisely because of their vulnerability, as acts of cowardice. 


\section{Terrorism and cultural values}

As something else than a criminal act, terrorism should be understood as a political act. However, moral philosophy recently asked to what extent victims and culprits are two sides of the same coin. What for some is considered an act of cowardice for others is lived as the fight for freedom. Quite aside from this, what the 9/11 attack signified was not only the failures of control in the airspace of the USA but also the onset of a new state of fear that invaded other countries worldwide. After all, the war on terror initiated by G.W. Bush's administration engendered more problems than solutions. In this context, Kucukaltan (2006) introduces readers to the slippery connection between tourism and terrorism. His thesis represents a serious academic effort to expand the current understanding of how tourism works worldwide and the impacts of terrorism on local economies. Travel and technological advances have certainly transformed the modern forms of displacement. If one pays attention to the fact that their high degree of mobility makes international tourists an easy target of terrorist cells, it is clear how after 9/11 the relationship between tourism and terrorism became more troublesome. After further examination of the economic factors that potentiate or mitigate a state of emergency, this insightful work suggests that tourism and hospitality are sensitive to economic inequalities. Ranging from inflation and increasing of prices to the ecological deterioration of non-renewable resources, economic crisis causes several profound problems to tourism simply because it makes pathways for political instability and terrorism. The consequences of terrorism might extend even to neighbouring countries, which is of paramount importance during policy making and planning. The primary point of discussion is associated with the belief that all wars as well as political crises correspond with the convergence among religious, economic, and ideological reasons. To some extent, Kucukaltan acknowledges that even if war shows negative aftermaths for local economies, the nostalgia for involved countries or the sentiment of nationalism can very well create a demand and boom for tourism and hospitality industries.

Similarly, Bianchi (2007) explains that tourism revolves around risk perception, which acts as conducive to the interests of some industrialised nations and to the detriment of the periphery. The ongoing state of insecurity created by terrorism references a political logic of exclusion. The paradox lies in that studies of risk perception themselves threaten the goal of security they encourage. To what extent does terrorism affect the tourism industry? Castaño (2005) propones the arrival statistics from 2000 to 2003 in some cities that had been targets of terrorist attacks. This dataset questions the belief that terrorism threatens tourism. Cities like Mombasa, New York, Madrid, London, Bali, and Cairo experienced notable declines in tourism, but they recovered within a few months. Terrorism may potentiate tourism by means of dark tourism - terrorism tourism. Castaño (2005) argues that terrorism is a reversible process. No matter the original impact on public opinion, given some unspecified time frame, what today generates fear, tomorrow will entice thousands of tourists. Hotel chains and tourism staff become targets of attacks because they symbolise the strength of an economic order that causes resentment and exclusion. If the West is named as the cause of all suffering, this diminishes the responsibilities of local elites who give their support to imperialist powers.

Steiner states that marketing and management literature is ignoring the complex relationship among risk, attractiveness, and tourism. Sometimes terrorism boosts tourist 
destinations. What changes in these types of events is the dynamic of tourism and its fluxes, not tourism as an activity. After 9/11 many Muslim destinations declined in visitations while others prospered. To what extent may tourism be considered a retractile activity? Steiner argues that terrorism affected the Western demand in Middle East but encouraged the intra-regional markets opening new opportunities for Muslim destinations. This engendered a two sided aftermath which alternates stabilisation with conflict. In spite of negative images portrayed by the media about the 9/11 attacks, people still move toward other regions.

\begin{abstract}
"the Events following 9/11 caused a recurring neighbourhood effect in various Muslim countries, which led to a decline in tourist arrivals. However, while some major destinations in the region severely suffered, others performed extremely well. From a theoretical point of view, this difference in the occurrence of a neighbourhood effect is somehow surprising and begged the question of how a varying emergence of neighbourhood effects and the varying development paths of different destination in the Muslim world after 9/11 could be explained" Steiner (2010, p.203).
\end{abstract}

To respond to why terrorists select some targets while avoiding others, Vukonic (2010) explores the importance of tourism in the Middle East. The Muslim World has suffered many changes caused by the advance of modernity and tourism. Although some countries keep a friendly relationship of cooperation and diplomacy with the West, others, like Iran, adopt an atmosphere of rivalry and conflict. What remains clear for Vukonic, is that Western travellers are sometimes attacked to take advantage of their lack of familiarity with the environs they visit and because of the cultural values they represent. Unless the state intervenes in their protection, tourism may offend local tradition and customs. In this vein, Vukonic explains that the religion/tourism connection may be detached in three primary ways:

a religion somehow supports tourism

b tourism somehow influences religion

c religion and tourism stand in opposition.

It is widely accepted that religion gives support to tourism only when religious norms are not defied or in danger. The four great religions depended and depend on pilgrimages and holy land explorations. To adhere to religious doctrine, psychical displacement and travels play a crucial role because they pave the way for the construction of infrastructure, shrines, and designated holy places. Under some circumstances, tourism exerts considerable influence on religion depending on the viewpoints of residents and participants. Some countries at odds may reinforce mutual understanding by means of tourism, even borrowing religious values from each other. Religion and tourism can be irreconcilable enemies in a way that reduces the peace promoting processes which prioritise intercultural differences rather than commonalities. Some practices introduced by guests may be incompatible with the religious beliefs of their hosts. In this case, two or more values may cause nonnegotiable discrepancies that lead groups to conflicts, and even warfare. Since tourism accelerates the intergroup connection, in such a context, conflict surfaces.

Throughout the Middle East and beyond, developing countries adopted tourism as a primary industry to adjust some economic asymmetries resulting from problems of governability, corruption, and bad administrations. Although in the short run, tourism 
brings fresh investments to host economies, states can develop a dependency on the tourism industry. Terrorists and insurgents may take advantage of this situation to affect the destination image. This way, they not only attack the state but also jeopardise its economy. Pro-tourist policies sometimes contrast with some radicalised beliefs. Therefore, terrorism is for Vukonic a glitch in the process of communication, an anomaly that makes tourism and religion not understand each other. Vukonic's argument is that in an intercultural meeting some groups are encouraged to improve their situations, while others do not. What is important to discuss is why terrorist attacks have been imported to the greater Western cities in recent years? Undoubtedly, 9/11 marked the starting point of a new frame of reference where citizens do not feel safe anywhere. The marathon bombing in Boston 15 April 2013 illustrates the point that public celebrations seem to be a playground for the operations of terrorists in USA cities. The problem with terrorism is that nobody knows when the next blow will take place. Terrorists today are educated in the best universities of West, some of them live legally in European or USA cities, and some are even citizens of the USA or European Union countries. The problem of terrorism differed substantially in earlier decades. To understand why terrorists select the public mega events for their attacks we first have to explore the world of mediated events and their psychological effects on society.

\section{The media events and safety}

From an anthropological perspective, festivals have an epicentre in the allegoric construction of meaning in relation to certain themes which concern the involved community. Events and festivals must be understood as rites whose essences resolve existential cultural contradictions. For example, societies have serious problems in intellectualising the death of children. Because of biological cycles, they are supposed to live more than parental generations. Event management corresponds with a rite of passage that describes the economic cycle of harvest.

Festivals represent not only certain denial of poverty and shortage expressed in banquets, but also emulates lost paradise through beauty and harmony. The influence exerted by mediating events is unquestionable. In a longitudinal investigation by Ritchie et al. (2007) in the capital city of Camberra in Australia showed that viewers subjected to mediated events had a more positive image of the destination than other groups.

Liang et al. (2008) assert that event management entails three benefits associated with enjoyment, socialisation, and appreciation. Supporting the findings of previous studies, the authors conclude that festivals and events not only contribute to the expansion of local economy but revitalise the commitment for being part of these events irrespective of the travelled distance. Following this, Crompton and Mckay (1997) suggest that six motives dominate visitors at the time of participating in a festival: cultural exploration, novelty, recovery needs, socialisation, external interaction, and gregariousness. Other effects of festival management are strictly related to the image change for a community (Prentice and Andersen, 2003), politically staged authenticity issues or guest and host's conflicts (Berlanga-Adell, 2004; Robson, 2005). Abundant literature identifies destination image maturity with mediated events (Jago et al., 2003; Lury, 2001). Reid and Ritchie (2011) say that safety in event management is the major topic to be covered by researchers. Risk management plans resulted from the previous belief hoteliers had of safety and security issues. Event managers are often concerned by physical and safety 
risk where the life of attendees was in danger while financial and other organisational secondary risks can be minimised. These specialists suggest that behaviour is explained by the sum of two factors, subjective norms and attitudes. The degree of control of the attendees is of paramount importance to create a sense of safety in the event venue.

Sports and media events are functional to the preservation of an organic image of destinations. Molloy dwells on the social benefits of festival organisation for the hosting community. She contends that festivals entail a new form of entertainment, in which relaxation and socialisation are promoted in a familiar climate allowing for fun and excitement to predominate. This type of action not only increases the quality of life but also integrates economic and human resources for development. An interesting point of Molloy's work is the role played by the state in event management. Like many other scholars, she accepts that the state intervenes with financial support for the organisation of festivals because it accrues a variety of benefits for interested communities (Molloy, 2002).

Sociological characteristics of mediated events are associated with a ceremonial performance based on two main goals:

"1) to show that the utopia as modeled has always been a driving force in the life of society, such that collective memory exhibits traces of continuous aspiration toward it, and 2) to confirm the feasibility of the proposed transformation by investing the wealth of aspirations in a popular program of action". [Dayan and Katz, (1994), p.180]

A media event ranges from the Olympic Games to a burial. To clarify, even if the word 'media' is identified in popular parlance with the use of television, this is not the case. Media refers to every aspects of human life that are public and reinforce the social commitment in day-to-day issues. Dayan and Katz (1994) define 'mediated events' as celebrations which exhibit a significant importance for the community because they not only strengthen the social bond, but also refer to a founding event in which the community ostensibly forged itself. These types of media events may include military parades, independence days, royal weddings, musical events, sports, and festivals.

In addition, one might admit that effects of mediated events are intended to prevent social fragmentation reinforcing the self-esteem of the entire group. That way, moments of instabilities or uncertainty are a prerequisite for the management of events. This happens because the pre-existing cultural values are often manipulated by privileged stakeholders to their own benefit. In this context, the elite are prone to fabricate facts regarding history to give their own, tendentious meaning to events so as to provide a specific discourse that nourishes a sentiment of belonging. Dayan and Katz enumerate seven characteristics of media events, which explain their importance for the social imaginary:

- media events strengths the legitimacy of elites

- these events resolve earlier stages of dispute or conflicts to forge a strong nationhood

- those leaders who take part of these rites embody a mythical archetype that links them to the lineage of founding parents

- media events not only change the boundaries of society for accepting or rejecting minorities, but also provide neologisms and linguistic resources to denote the new situation of celebration 
- $\quad$ like a dream, events act as ideological mechanisms to foster legitimacy of leaders over their citizens.

Dayan and Katz (1994) explain that media events are important to improve the mechanisms of reinforcement and reproduction of societies. Following this, most of the message in these spectacles corresponds with the legitimating of elites and assurance of a broader national being. If some rebellious groups want to cause psychological distress in the community, these types of events offer a particularly fertile space to inflict damage to the society.

Howie (2012) acknowledges the fact that the world and economies have changed forever since 9/11. Given the obsession for security in USA, Howie's research shows how the intervening years have changed the interviewees' viewpoints. There is a strong complicity between terrorists and journalism. Howie's 2012 book examines the limitations of extant conceptual frameworks, and in parallel to other studies, connects the theories of terrorism with late modernity. Howie says terrorism should be defined as more than a political technique or strategy. Instead, terrorism lies in the witness's terror. Terrorism is designed to cause psychological fear, not to obliterate populous cities. In this it contrasts with the mass warfare of the Second World War or the potential war played out over the forty years of the Cold War. Globalisation plays a pervasive role by homogenising the domination of technology, economic linkages, and rationalisation; while on another hand, it entails a process of re-territorialisation based on a bipolar logic of inclusion/exclusion. At the present time, tourism triggers the worldwide displacement of the global system's centre and its recently erected walls and barriers to prevent the crossing of peripheral workers. Poverty and lack of perspective pave the ways for the upsurge of national movements. Even though terrorism can be part of the social discontent that led people to resentment, some groups as in Spain or Ireland opt to participate in politics to gain constitutional representation in the parliament (Del Bufalo, 2002). It is important to note the connection between terrorism, violence, and the law. Whenever some groups are pushed to peripheral conditions, or restricted in political life, they revert to violence as a form of persuasion. When this happens, political discourse sets the pace toward violence (Connolly, 1994). Political terrorism engenders a subtle but powerful message, which in this section we decipher.

\section{$5 \quad$ Leisure and terrorists}

As the incident of the 15 April 2013 Boston marathon bombing shows, terrorists need public attention. This attention is instrumentalised to achieve their goals, regardless of human safety. Because leisure spaces, especially where mega events occur, are of paramount importance for gaining attention, many terrorists try to accelerate negotiation with states by means of violence in those venues. Munné and Huizinga have demonstrated that leisure is enrooted in the social fabric of society. Leisure, according to Munné, is an ideological instrument of indoctrination that makes sense of the environment (Munée, 1999). Huizinga (1968) emphasises the agonistic nature of competence to define the importance of leisure in the modern world. Hommo-Ludens, one of his most famous works, discusses the role of play in the society as a catalyst towards social bonds. Culture is generated by the imposition of play. Following this argument, Huizinga argues that the act of play encompasses five characteristics: 
a play surfaces from the ordered freedom

b play emulates an outstanding archetype that goes beyond the normalcy

c in opposition to the ordinary, play is framed in a specific time and space

d although it seems to be chaotic, play exhibits the need of rules and order

e play is subject to non-monetary goals.

Linguistically, Huizinga says that play is excluded from the logic of labour, which situates it in the leisure sphere, and it also enables the principle of civilisation (Huizinga, 1968). The sphere of leisure does apply specific rules, which if broken undermine social trust. Furthermore, leisure opens the doors for uncertainty and ambiguity. Dunning and Elias explain that war and sport represent two different kinds of conflicts that alternate subordination, independence, cooperation, and loyalty. As a vehicle towards pleasure or displeasure, both war and sport connote a combination of rational and irrational behaviour. Furthermore, the existence of contrasting ideologies suggests that sport works as a substitute for war by decreasing the brutality of players. The progress of civilisation depends on the degree to which violence can be disciplined. The civilising process of West is based on three combined factors:

a centralisation of control in a much broader administrative apparatus

b the monopoly of violence exerted by the state alone to foster the security and well being of a community

c the ability to introduce in members the social values that keep the society functioning.

Although the state keeps a monopoly of violence by means of technology, and police, the external frontier plays a pivotal role in the process of identity. Leisure and sports seem to be efficient instruments, not only to sublimate the individual violence into acceptable levels, but also to alleviate the daily burden created by the production-led logic of modern capitalism. The deprived self is dangerous to itself and for others. Therefore, modern society tries to control the degree of deprivation its citizens face. The quest for excitement that characterises the world of leisure appeals to a deep-seated discourse so that the self can be duly regulated. In the spaces of leisure, people express their most profound emotions, which remain repressed in normal conditions. What is important to debate respecting to the leisure seems to be the propensity of society to weaken its dispositive control so that emotions may flourish. In doing so, it is not surprising to see that leisure sites are characterised by controlled violence and conflict. But as Elias and Dunning put it, under some conditions this controlled status changes to a state of crisis. This seems to be the reason why not only terrorist-led attacks select international mega-events as primary targets, but also how riots or revolution are initiated in leisure spaces (Elias, 1992a, 1992b; Elias and Dunning, 1992a, 1992b).

Leisure plays a pervasive role because it follows the expansion of empires in the world but at the same time, it weakens the process of control in urban cities. Gomes and Elizalde (2012) introduce in the discussion the idea that leisure does not represent an attempt at recreation or a space of free time. Leisure rather, corresponds with the creative view of changing the environment. Leisure spaces are determined by an encounter between two contrasting forces, which appeal to a state of tension, in which order and 
disorder converge. In this regard, Igarza (2008) acknowledges that leisure adapts to the existent technology, which leads people to be controlled by technology's structure, but at the same time it entails a change. In sharp contrast with other eras of mankind, the boundaries of leisure and work are gradually becoming blurred. To date, digital technological advances have facilitated faster and more secure access to a broader, interconnected world of information outside of the traditional nation-state control. The question as to whether people can enter a virtual reality and displace their bodies without physical movement became one of the more exciting issues of modernity that social science is just beginning to examine. In another respect, if the term globalisation seems to be a hard concept to grasp even for scholars, the fact is that a growing number of consumers take advantages of digital leisure at work or in schools. Consequently, work time is suffering a radical shift based on a tendency to leisure breaks during work. No less than four decades ago, workers spent their time in one duration, and only stopped once or twice in the day for a recreation for few minutes. Igarza argues that the same technologies people use for working purposes in an office are adaptable for recreational needs. Paradoxically, a process of urbanisation has generated megacities, while at the same time it allows a disaggregation of impersonal persons who increasingly communicate through digital mass consumption, as in networked workers.

Modern cities are characterised by a merger of multiculturalism and cosmopolitanism wherein passers-by often walk or cross avenues rushed by their duties living in the core of vertigo. This hectic style of life seems to be in the quest for more exciting experiences irrespective of the source consumers follow for their recreational needs. The increasing complexity of labour leads workers to an overburdened atmosphere. Recreation and leisure play a crucial role in preserving and refreshing the mind of worker. Recreationists need to escape from rules and state control. This seems the reason why states fail to prevent terrorist attacks in the context of festivals. As noted in earlier sections, terrorism does not obliterate cities or kill thousands of people; they want to encourage a situation of extreme fear alone. Therefore, it is important to understand the psychological effects of terrorism in Western societies.

\subsection{Towards a new theory in terrorism prevention policies}

It is important not to overlook that not all risks are the same or have the same psychological effects in society. While some risks are often trivialised even though their potential effect would be apocalyptical, others are exaggerated. Risk perception theory explains that the frames of risk are manifold. The following risks are enumerated as the most important studied by literature as factors that may destabilise systems:

a unknown virus and pandemics expanded by international travels

b food safety

c terrorist attacks against civilians

d airplanes or road accidents

e natural or made-man disasters

f crimes, theft against tourists

g political upheaval or instability. 
Although each one of the subtypes of risk engenders diverse effects on the tourist mind, we will only deal with terrorist-related acts. To measure the impact of terrorism, we have to evaluate two relevant aspects: the probability of damage signals and the possibility of real harm that a person or the community face in a certain period of time. The effect on social imagination explores the cognitive construal of the risk. Here, conceptual variables are more important for understanding the selectivity of risk perception for a tourist. While many Western tourists trivialise local crime in context of mega events, or attacks produced by the abuse of alcohol, other major risks that seem less probable are emphasised as factors which influence in their destination choice. This seems to indicate that the effects of perception are rooted in the communication process. Sometimes, how these effects are handled are more important than real damage. Sunstein (2006) explains that one of the problems of states is to follow the populist demands of its citizens. First and foremost, citizens are subject to biased impressions of reality that exclude the objective diagnoses of scientists. Those states which claim to cover all safety claims of citizens are involved in a spiral of fear mongering. Lay people misdiagnose the real reason for disasters, including terrorism. They seem to be influenced by the effect alone, and, of course, by the fabrication of news by the media. At the same time, some crimes are considered disgusting, when they are perpetrated on vulnerable targets as women or children, while others are accepted, as when a police officer shoots a delinquent. Policy makers in mega events pay attention to the psychological impacts of risk in tourism and hospitality. Whenever civilians are the targets, public opinion reacts to the attacks, placing their government under the lens of scrutiny.

The psychological impact of terrorism in the media and on the audience is based on three points:

a control threshold

b probability of repetition

c the status of the victims.

Table 1 Psychological impact of terrorism in leisure context

\begin{tabular}{lccc}
\hline Control threshold & Probability of repetition & Targeted victims & Impact \\
\hline Low & High & Tourist & High \\
High & Low & Tourist & Low \\
Low & Low & Tourist & High \\
High & High & Tourist & Low \\
\hline
\end{tabular}

The control threshold refers to the ability of the system to predict the time and place of the attack. The probability of repetition measures the mobilisation of resources to prevent traumatic events. The probability of repetition is proportionate to the effects of events that cannot be avoided. Finally, whenever victims are valorised by their high social status, the impact on social imagination is greater than cases where low status people are affected. This explains, for example, why some few Western tourists have more value than thousands of Palestinians. Terrorists not only recognise this, but also look to attack travellers to have a greater impact on First World states with an immediate decline for the tourism industry. The degree of dependency between tourism and economies in Third World is of paramount importance to understand why they are targets of violence. 
Table 1 exemplifies and summaries of our argument based on tourism and hospitality only.

Nationality is a variable that correlates with the amount of fear. If tourists are American or British, representing the Anglo alliance, the impact is greater than if victims are Argentines or Brazilians. Also it matters whether the victims are tourists or local residents. For example, when the control threshold is high as well as its probability of repetition, the impact is paradoxically low simply through a process of normalisation. For those events that are constantly repeated, the audience becomes inured to the event and its original impact is undermined. Therefore, natural disasters are more fearful than terrorist attacks. The first combination shows how the impact turns high when the attacks on tourists not only keep a low control threshold - i.e., when the state is unable to prevent the act - and the probability of repetition remains high, suggesting that the state does not have the ability or technology to prevent the next attack. The impact is low if the state develops sufficient resources to control the situation, reducing the odds of repetition. If both the control threshold and repetition probability are low, the impact is high. No matter the probability of repeat, if people think the state is unable to protect then, the process of political instability starts. Last but not least, if the control threshold and repetition probability are high, then the impact changes to low, because the terrorist attacks are normalised. This last point pertains to extent that the public lacks a sensibility of violence and empathy for the suffering of others by media exposure. To some extent, this explains the complicity between media and terrorists. The former domesticates the political instability by over exposure while the latter needs media coverage to transcend the boundaries of state. What remains, is that both feed logic of hate and conflicts. While Western states claim the right of intervention in case of potential terrorist acts, terrorists build a discourse of resentment based on the state's reaction.

\section{Conclusions}

In the present essay-review we have discussed the limits of terrorism, its logic, as well as how attacks are planned. Leisure spaces in the global geography are fertile grounds for terrorist acts. Mega-events and festivals exhibit a much broader impact in the social imagination of any community. Affecting the meaning of mega-events, by imposing violent attacks, is a way of creating instability. Unfortunately, the extant safety policies in event management are unable to detect the differences of risks, or to evaluate a clear diagnosis of the messages terrorists generate when they attack civilians. The event management and hospitality industry will reformulate in the next few years policies to help to protect civilians, understanding first that the needs of terrorists are linked to the media. We have provided here a coherent and all-encompassing view as to why terrorists select the mega-events as the primary target of their onslaughts. In the following we summarise the characteristics of terrorism which uses tourism to cause damage to the state:

a Terrorists tend to speculate in order to cause the major impacts on popular sensibilities.

b Hospitality and tourism act as a fertile source to entice terrorists' attention.

c Vulnerable victims receive the attention of the media. 
d The state loses its legitimacy when the most vulnerable actors are attacked. This happens simply because the message is: nobody can protect you.

e Leisure and tourist-friendly climates weaken the rules.

f Discrediting the state is one of the most efficient messages of terrorism.

$\mathrm{g}$ Whenever the goals of terrorists outweigh the means, the life of people has no worth.

$\mathrm{h} \quad$ It is very difficult for the state to regulate behaviour in context of leisure and festivals.

From our point of view, terrorism is a dialectical process between opposing interests which uses violence to gain its ends. This dialectic is not exclusive to a group or a state, but the connection between both. Terrorism has elements or primary aspects that define its existence:

a speculation

b violence

c attacking vulnerable non-combatants

d compliance with the media or journalism

e surprise factor.

Skoll (2007) explains that the function of the state is to maintain the hierarchical status quo by exerting power and violence over populations. In times of low conflict, the legitimacy of the state rests on the market which confers certain stability. In the context of relative chaos and disorder, the state resorts to violence to refashion the threatened order. Similarly, the market mediates among human beings by imposing a state of gratification in lieu of constraints, but the moment the control weakens, fear replaces gratification as motivator to legitimise the ruling order (Skoll, 2007). Terrorism, however, operates as a mirror of Western style of life. Terrorists are not ill-minded persons who want to destroy our civilisation, but a radical experiment of connecting with otherness. Terrorists, let us remind the readers, were educated in the best Western universities, they earned a degree in management or even a $\mathrm{PhD}$. What they learned from the West is how to use leisure to negotiate based on violence and speculation. What many terrorism analysts ignored is that theories of management and marketing studies have facilitated the plans of al Qaeda in synchronising the 9/11 or Boston 2013 attacks.

\section{References}

Abdel-Azim, T.S. (2010) 'The relationship between the perception of risk and the decision making process of travel of French tourists: the case of Egypt', Tourismos, Vol. 5, No. 2, pp.29-47.

Atkins, B. et al. (2003) 'The impact of terrorism on tourism and hospitality business: an online debate by experts in the field', Tourism and Hospitality Research, Vol. 4, No. 3, pp.262-267.

Baker, K. and Coulter, A. (2007) 'Terrorism \& tourism: the vulnerability of beach vendors livelihoods in Bali', Journal of Sustainable Tourism, Vol. 15, No. 3, pp.249-266.

Berlang-Adell, M.J. (2004) 'Turismo y Poder: las transformaciones de una fiesta popular en Marruecos', Pasos: Journal of Tourism and Cultural Heritage, Vol. 2, No. 1, pp.25-45. 
Bianchi, R. (2007) 'Tourism and the globalization of fear: analyzing the politics of risk and (in)security in global travel', Tourism and Hospitality Research, Vol. 7, No. 1. pp.64-74.

Castaño, J.M. (2005) Psicología Social de los Viajes y el Turismo, Thomson Ed., Madrid.

Cohen, R. (1990) Culture and Conflict in Egyptian-Israeli Relations: A Dialogue of the Deaf, Indiana University Press, Bloomington.

Connolly, W. (1993) The Terms of Political Discourse, 1st ed., Princeton University Press, Princeton.

Cooper, H.H.A. (2001) 'Terrorism: the problem of definition revisited', American Behavioral Scientist, Vol. 44, No. 6, pp.881-893.

Crenshaw, M. (1983) 'Introduction: reflections on the effects of terrorism', Terrorism, Legitimacy, and Power, pp.1-37, Wesleyan University Press, Middletown CT.

Crenshaw, M. (1995) 'Thoughts on relating terrorism to historical contexts', Terrorism in Context, pp.3-24, Pennsylvania State University Press, University Park PA.

Crompton, J. and Mckay, S. (1997) 'Motives of visitors attending festival events', Annals of Tourism Research, Vol. 24, No. 2, pp.425-439.

Dayan, D. and Katz, E. (1994) Media Events. The Live Broadcasting of History, Harvard University Press, Cambridge.

Del Bufalo, E. (2002) 'La Restructuración neoliberal y la globalización', in Ceceña, A. and Sader, E. (Eds.): Guerra Infinita: hegemonia y terror mundial, CLACSO, Buenos Aires, pp.39-62.

Elias, N. (1992a) 'Introduction', in Elias, N. and Dunning, E. (Eds.): Sport and Leisure in the Civilizing Process, pp.30-81, Fondo de Cultura Económica, Buenos Aires.

Elias, N. (1992b) 'Genesis of sports as a sociological issue', in Elias, N. and Dunning, E. (Eds.): Sport and Leisure in the Civilizing Process, pp.157-184, Fondo de Cultura Económica, Buenos Aires.

Elias, N. and Dunning, E. (1992a) 'The quest for excitement in leisure fields', Sport and Leisure in the Civilizing Process, pp.83-115, Fondo de Cultura Económica, Buenos Aires.

Elias; N. and Dunning, E. (1992b) 'Leisure under spectrum of free-time', Sport and Leisure in the Civilizing Process, pp.117-156, Fondo de Cultura Económica, Buenos Aires.

Floyd, M. and Pennington-Gray, L. (2004) 'Profiling risk: perception of tourist', Annals of Tourism Research, Vol. 31, No. 4, pp.1051-1054.

Gomes, C. and Elizalde, R. (2012) Horizontes Latinoamericanos del Ocio, Editorial, Universidade Federal de Minas Gerais, Belo Horizonte.

Hall, M. (2002) 'Travel safety, terrorism and the media the significance circle of the issue attention cycle', Current Issues in Tourism, Vol. 5, No. 5, pp.458-466.

Henderson, J.C. (2008) 'Managing crises: UK civil aviation, BAA airports and the August 2006 terrorist threat', Tourism and Hospitality Research, Vol. 8, No. 2, pp.125-136.

Howie, L. (2012) Witness to Terror: Understanding the Meaning and Consequence of Terrorism, Palgrave, New York.

Huizinga, J. (1968) Hommo Ludens, Emece, Bogota.

Igarza, R. (2008) Leisure's Bubbles: A New Form of Cultural Consumption, La Crujia, Buenos Aires.

Jago, L. et al. (2003) 'Building events into destination branding: insights experts', Event Management, Vol. 8, No. 1, pp.3-14.

Korstanje, M. (2009) 'Re-visiting the risk perception theory in the contexts of travels', ERTR: E-review of Tourism Research, Vol. 7, No. 4, 68-81.

Kozak, M, Crotts, J. and Law, R. (2007) 'The impact of the pereption of risk on international Travellers'. International Journal of Tourism Research, Vol. 9, No. 4, pp.233-242.

Kucukaltan, D. (2006) Tourism and Terrorism: an Experience of Turkey and the World, Universe, Nebraska. 
Kuto, B. and Groves, J. (2004) 'The effects of terrorism: evaluating Kenya's tourism crisis', Pero ¿como definir un acto 'terrorista?, E-review of Tourism Research, Vol. 2, No. 4, pp.88-95, Texas A\&M University, USA.

Lepp, A. and Gibson, H. (2008) 'Sensation seeking and tourism: tourist role, perception of risk and destination choice, Tourism Management, Vol. 29, No. 1, pp.740-750.

Liang, Y., Illum, S. and Cole, T. (2008) 'Benefits received and behavioral intentions of festivals visitors in relation to distance travelled and their origin', International Journal of Event Management Research, Vol. 4, No. 1, pp.12-23.

Lury, G. (2001) 'Thoughts on decision branding, British bulldog days are numbered', Brand Strategy, pp.1-3.

Molloy, J. (2002) 'Regional festivals: a look at community support, the isolation factor and funding sources', The Journal of Tourism Studies, Vol. 13, No. 2, pp.2-15.

Moten, R.A. (2010) 'Understanding terrorism: contested concept, conflicting perspectives and shattering consequences', Intellectual Discourse, Vol. 18, No. 1, pp.35-63.

Munée, F. (1999) Psicosociología del Tiempo Libre, Editorial Trillas, México.

Peattie, S., Clarke, P. and Peattie, K. (2005) 'Risk and responsibility in tourism: promoting sun-safety', Tourism Management, Vol. 26, No. 3, pp.399-408.

Prentice, R. and Andersen, V. (2003) 'Festivals as a creative destination', Annals of Tourism Research, Vol. 30, No. 1, pp.7-30.

Reid, S and Ritchie, B. (2011) 'Risk management, event managers attitudes, beliefs and perceived constraints', Event Management, Vol. 15, No. 4, pp.329-342.

Ritchie, B., Sanders, D. and Mules, T. (2007) 'Televised events: shaping destination image and perception of capital cities from the couch', International Journal of Event Management Research, Vol. 3, No. 2, pp.12-23.

Robson, L. (2005) 'Risk management for meetings and events', Annals of Tourism Research, Vol. 35, No. 3, pp.840-842.

Skoll, G. (2007) 'Meaning of terrorism', International Journal for The Semiotics of Law, Vol. 20, No. 1, pp.107-127.

Steiner, C. (2010) 'Impacts of September 11: a two sided neighborhood effect?', in Scott, N. and Jafari, J. (Eds.): Tourism and Muslim World, pp.181-202, Emerald Group Publishing, West Yorkshire.

Sunstein, C. (2006) Riesgo y Razón: seguridad, ley y medioambiente, Editorial Katz, Buenos Aires.

Tarlow, P. (2011) 'Tourism risk management in the age of terrorism', in Korstanje, M. (Eds.): Economía Autonoma, Vol. 7, No. 1, pp.25-40.

Task Force on Disorders and Terrorism (1976) Disorders and Terrorism, National Advisory Committee on Criminal Justice Standards, Washington DC.

Vukonic, B. (2010) 'Do we always understand each other?', in Scott, N. and Jafari, J. (Eds.): Tourism and Muslim World, pp.31-45, Emerald Group Publishing, West Yorkshire.

West, B. (2008) 'Collective memory and crisis: the 2002 Bali bombing, national heroic archetypes and the counter-narrative of cosmopolitan nationalism', Journal of Sociology, Vol. 44, No. 4, pp.337-353. 